\title{
ROMANIAN SMALL TOWNS SEARCHING FOR THEIR IDENTITY
}

\author{
Daniela ZAMFIR, Cristian TĂLÂNGĂ, llinca Valentina STOICA \\ University of Bucharest, Romania
}

\begin{abstract}
Romanian small towns - urban settlements of less than 20000 inhabitants having a polarizing function with respect to the socio-economic activities in the deeply rural areas - are considered an interface between rural and urban communities. Determining the identity of small towns is rather difficult, because complex and varied political, social and economic changes occurred in the previous century. Thus, three distinct phases have been established: before 1950 the towns had a rather strong rural character; in 1950-1989 their identity was completely changed under the communist regime; after that, they somehow regained their initial identity (the one before 1950), or promoted it at higher levels. There is a discrepancy between the present stage and that before 1989: the previous identity was conventional and constrained whereas today it develops in a natural process conditioned only by the town itself and by the choice of its inhabitants.
\end{abstract}

Key Words : identity, small towns, functional profile, Romania.

\section{Introduction}

The concept of "identity" is a very complex one. Its approach implies a thorough knowledge of the characteristics of towns and of the historical, socio-economic and political changes which caused their emergence and dynamics. The present paper analyses the numerical and population evolution of the small towns in the interval 1912-2007 and the changes on their functional profile. In our opinion, these topics are the most important aspects in finding the identities of small towns.

In Romania, small towns represent the urban settlements with less than 20000 inhabitants. They are considered the basic unit of national settlements, having a polarization function of the socio-economic activities in closed rural areas. This function is induced by geographical analyses and legal documentation within the "Planning the National Territory Development" in force, section "Network of Localities".

At this moment, small towns, defined according to a dimensional criterion, represent more than half of the Romanian urban localities. These entities entail various demographic and economic aspects, and also historical and regional influences; they are fundamentally different and, at the same time, similar. The two characteristics may seem paradoxical when associated. However, they represent a link between rural and urban communities. More exactly, all small towns are situated at the level of rural and urban mixed characteristics within the national system of settlements. Therefore, they are defined both by urban and rural characteristics: demographic behaviours, economic functions, settlement patterns, life standard - in fact a very complex landscape revealing a rather curious mixture. The "small town" is ambivalent and hybrid, strange and singular. This makes its identity and sets it apart from the superior medium or high - urban units and from the nearby rural areas. 
There are 161 small towns in Romania. They have a well-balanced territorial distribution in the main relief units and practically cover the whole country; however, the majority is in the mountainous area (41 towns) and in tablelands (42). These categories of towns represent old urban units and they are, generally speaking, the result of a long development process. Some others are post-war towns, established to balance the network of settlements (at the county or area level) or to polarize deeply rural areas.

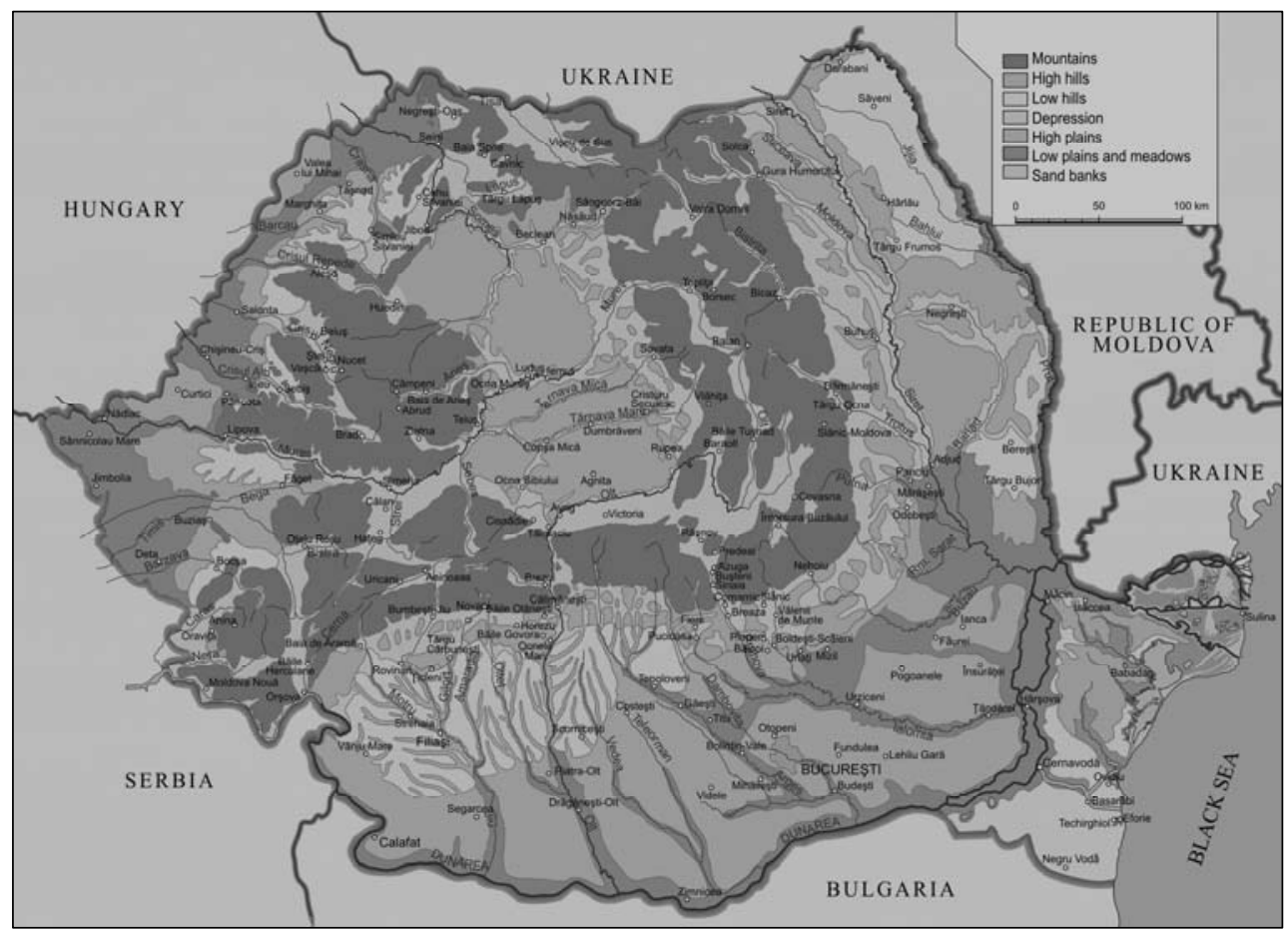

Fig. 1 - Well-balanced distribution of small towns in Romania

Depending on their position in the national network of settlements, mainly versus a town from a superior category or versus a deeply urban area, there are several types: ${ }^{1)}$

- Isolated towns in the national network of settlements with varied functions and acting as a relay between medium-sized towns and rural areas (Agnita, Târgu Lăpuş, Ineu, Câmpeni, Moldova Nouă, Chişineu Criş, Sulina, Urziceni a.s.o.);

- Towns situated close to urban centers or integrated in urban areas, which represent a source of commuters for nearby towns (Boldeşti-Scăieni, Otopeni, Bolintin Vale, Cisnădie) or tourist places (Valea Prahovei cluster) or mining towns (Țicleni, Rovinari, Baia Sprie).

The conclusion is that the towns situated in rural areas have better chances to develop, due to their geographical position, economic level and facilities; they could have an inter-regional function, but, if so, they need both improvement and services. "Isolation" in this case may have a positive function as regards the small towns situated nearby urban densities which, in time,

1) lanoş I. (1987), Orașele și organizarea spațiului geografic, Editura Academiei, Bucharest. 
would be assimilated by them and become "vast dormitories", totally depending on the nearby city and finally loosing their own identity.

\section{Emergence Stages of Small Towns}

Before discussing the emergence stages of small towns (and not only) in Romania, several aspects should be clarified in order to ascribe the administrative status of "town" in Romania, i.e. by law. The method is questionable, because during the socialist regime only few towns had been given this status on the basis of a correct decision able to prove that they deserved to become towns.

Related to the emergence stages, several "genetic" types can be established which reveal, to a certain extent, the arbitrary aspect of political decisions:

a) towns, as a consequence of a locality natural development;

b) towns, as a result of changing the administrative status of several localities;

c) new towns, as a result of some arbitrary political decisions.

In 1912, at the beginning of the 20th century, small towns represented $2 / 5$ of the Romanian urban population. If eighty years later they represented only $1 / 8$, at present the share is even smaller. The decreasing tendency of the population concentrated in small towns is not a characteristic of Romania. At the same time, the stage of enhancing the urbanization process had in view, mainly, big towns or cities. Small towns, as the base of urban pyramid, represent a very dynamic category. Among the contemporary small towns, there are some with deep ori-gins in the Middle Ages or even in Antiquity - the towns nearby the Danube: Orşova, Hârşova, Isaccea, and Măcin. Out of the 96 towns existing in the first half of the 20th century, only 29 still exist; the rest had different evolutions (8 of them returned to the rural locality status, while the majority changed into superior categories). The development process to new towns had different phases in time. Thus, between 1912 and 1948 the network of small towns increased: in 1930, 28 localities were declared towns. At the same time, 12 towns returned into medium-sized towns. Between 1984 and 1990, five times more towns were declared than in the previous period of time. Conferring the town status to a great number of rural localities in the post-war period was a process based on the existence of several urban rudimentary or embryonic criteria (Deică, Erdeli, 1994). Among these localities, there were also mining centers of extractive industry or administrative centers at the local level. Simultaneously, by conferring the "town" status, those towns became centers of the new-born industry. Thus, we can say that industry was the main factor in the emergence of these towns.

Although small towns developed during a long period of time, several important stages stand out in their evolution, namely: before 1948, 1949-1967, 1968, 1969-1988, 1989, 1990-2002 (Fig. 2). These stages were chosen considering that small towns centralized considerably in these periods of time, two of them representing the years in which the administrative status changed for many settlements in Romania.

In Romania, the present is a time of open possibilities, mobility and varied enterprises at all levels. Under the above-mentioned circumstances, the very nature of the village-town interactions is redefined. Following the gradual breakage of rural isolation and the busy interactions between rural communities and the nearest urban centre, the inhabitants move to the nearest town. The displacement phenomenon develops due to schooling facilities and to the training level which has considerably increased in the past few decades. If in the past, the

2) Deică P., Erdeli G. (1994), Les petites villes de Roumanie, Institute of Geography, Romanian Academy, Bucharest. 
nearest town was given preference over others due to its administrative aspects or to children's schooling, at present the movement has become more and more frequent. Everywhere, the traditional market-towns have been replaced by small centers offering rather special services and goods; trade, workshops, and sometimes small industries have developed due to a new generation of economic agents who take advantage of all the opportunities, or give a solution to the needs pending from the previous communist regime. Along with these changes of the relations between rural areas and small urban settlements, but with no obvious cause, the population dynamics of the towns situated on the top of urban hierarchy has altered: several towns have slowed down while rural areas experience a certain positive evolution. Within these changes of spatial configuration, and against the new economic background, it is obvious that small towns are more likely to interfere with these changes, because they are situated at the border between rural and urban communities.

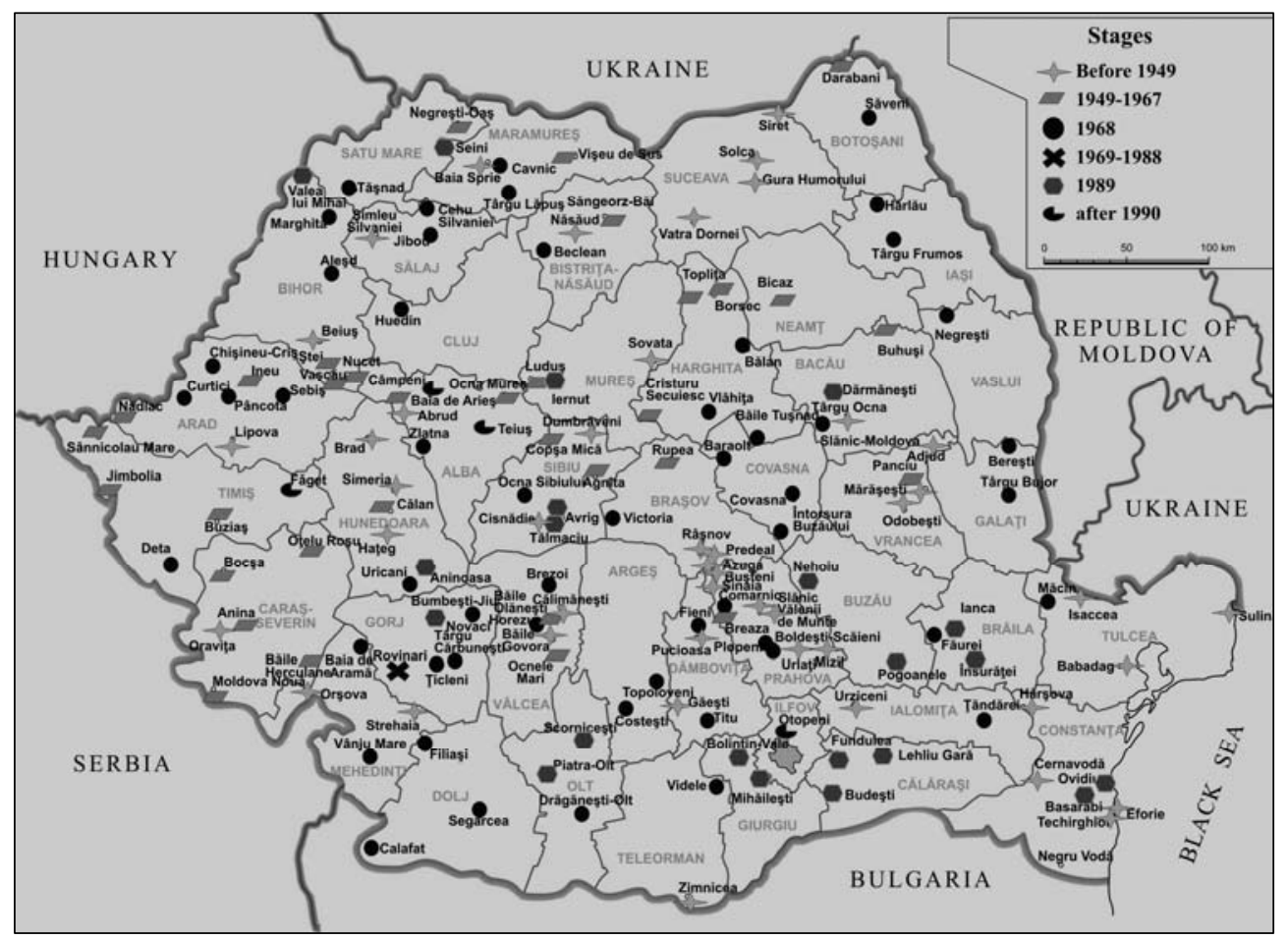

Fig. 2 - Emergence stages of small towns

Several parameters have been calculated to find out the identity of small towns: the attractiveness coefficient, the development level or growth index, and the degree of rurality.

\section{Small Towns - An Interface between Rural and Urban Communities}

The notion of "small town" is, by its essence, relative. Seen from a county capital point of view, small towns are analyzed as being part of the rural community; seen from a rural area point of view, small towns include elements of the urban system. It is not easy to determine, in a strict manner, the limits or boundaries between rural and urban communities: several small towns 
have complex characteristics of both rural and urban settlements. Then, how can we differentiate small towns from rural localities which "represent something more than simple communes in the hierarchy?" (Renard, 1997). However, beyond this vague limit between rural and urban areas, small towns should be valuated taking into account the local or regional background, density and urbanization level, which are basic parameters; thus, a small town integrated into an urban density will not have the same characteristics as an isolated one. Therefore, the isolation level of the town and its approachability degree should be considered as well.

To better illustrate the interface aspect between rural and urban communities we have chosen, out of many parameters, only three very significant ones which show the likeness between some of the small towns and rural community, namely: the attractiveness index, the growth index and the rurality index.

If nowadays we analyze the attractiveness of small towns in comparison with the area around them, we can still see the strong consequences of the interfering socialist policy. Therefore, the study of the attractiveness qualification of that urban category seemed highly relevant, by defining the attractiveness index. It was calculated as a simple ratio between the entire population at the locality level and the population with a permanent residence in that area. If its value exceeds 1 or 100 (if the final result multiplies by this number), the area is attractive; if the value is below this level, then it is a source of labour and population for other localities, superior towns namely. In 2002, the index value was, as regards small towns, between $96.78 \%$ (Bălan) and $104.63 \%$ (Predeal) (Fig. 3). The difference is considerable and the two towns confirm the theory that the former industrialized towns are no longer attractive for the surrounding area, because the industrial giants of the socialist period have disappeared. They have been replaced by towns of tertiary level, generally traditional, that have thus regained their place in the hierarchy. Almost $70 \%$ of the small towns have lower values than $100 \%$, being "repellent" to environment and incapable of attracting people. This is a direct consequence of the troubled economy after 1990, the majority having an unstable profile because of the changes in industry (Copşa Mică, Călan, Ocnele Mari, Găeşti, Strehaia, Mizil, Vlăhița, Ticleni, Scorniceşti, etc). Only $30 \%$ of these small urban centers are attractive, especially those with a well developed tertiary sector (Sinaia, Eforie, Sovata, Rupea, Otopeni, etc.), those which resumed their agricultural profile (Însurăței, Valea lui Mihai, Fundulea, Lipova, etc.), or those situated in deeply rural areas, which represent the only "chance" for the population of the nearby rural area (Sulina, Abrud, Negru Vodă, Segarcea).

The conclusion is that the towns with important industrial activities in the past have become less attractive whereas the attractiveness of the small towns with no significant industrial activities has increased as a consequence of the land allotment Law no. 18/1990, or of the development of some small tertiary poles which offer employment (even seasonal work).

The method of calculating the development index (Hull score) is quite simple:

$\mathrm{Gi}=50+14\left(\mathrm{I}_{1}+\mathrm{I}_{2}+\mathrm{I}_{3}+\ldots \mathrm{I}_{\mathrm{n}}\right) / \mathrm{n}$, taking into account the following indexes: inhabited surface $(+)$, migratory balance $(-)$, physician/inhabitant, population share of over 65 years old in the total population (-), population occupied with agriculture $(-)$, share of illiterate persons in the population of over 12 years old (-), infant mortality (-), phone license (+); these data are standardized for all cases.

3) Renard J. (1997), Les bourgs ruraux, in Bourgs et Petites villes, Acte du Colloque de Nantes, Presses Universitaires du Mirail, Coll Villes et Territoires, Toulouse. 


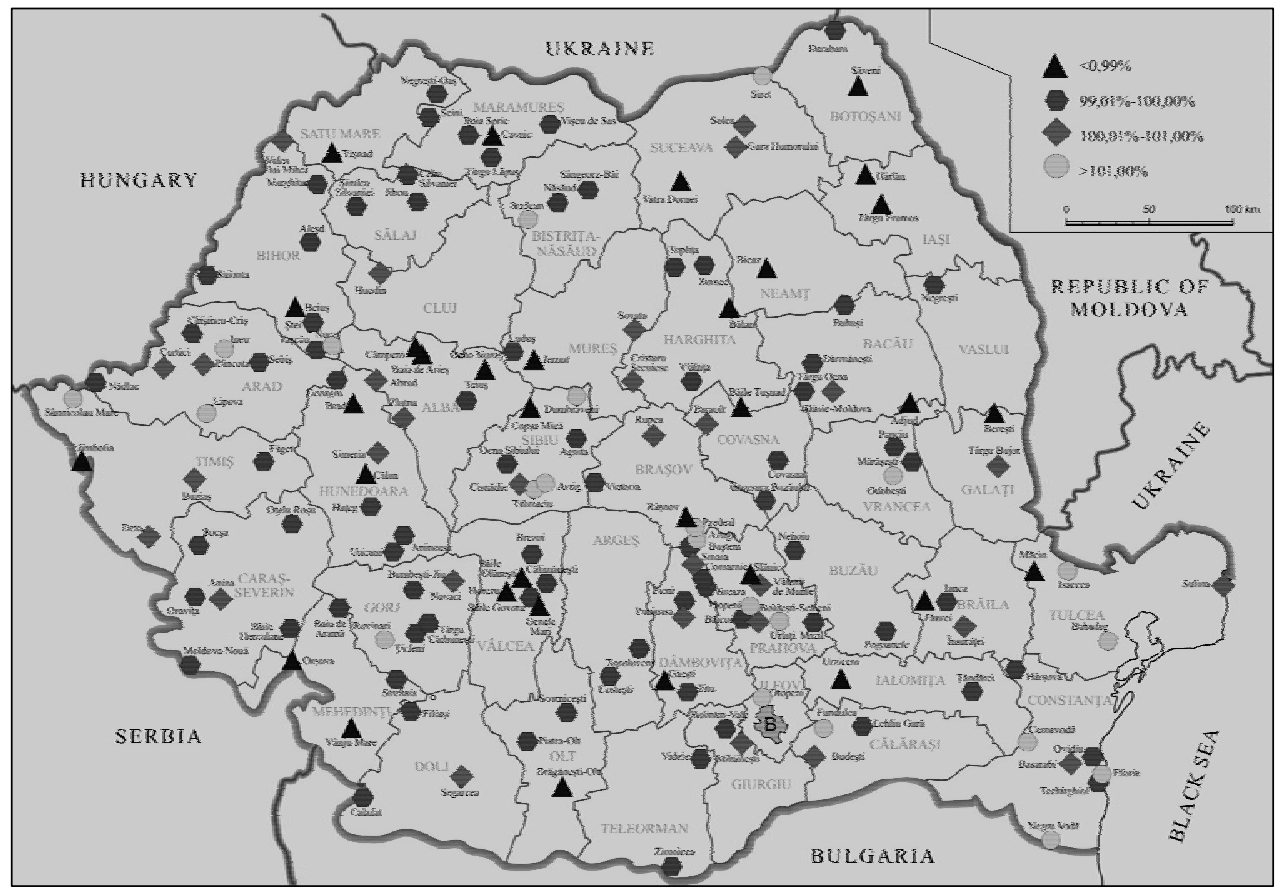

Fig. 3 - Attractiveness index

There have been established several classes of values which reveal a diversity of socioeconomic criteria in small towns, the HULL score oscillating between 48.5 and 52.0 (Fig. 4). The smallest values are concentrated in the southern and south-eastern regions of the country (they cover the Romanian Plain and the south of the Moldova Tableland), where the towns are relatively new: many of them were declared towns between 1968 and 1989. For this reason the socio-economic development is insignificant as well, since they have not a genuine urban tradition. At the upper limit are the towns in the Prahova Valley, well known for their urban attractiveness, but also other towns with a rather important industrial development in the past (Plopeni, Năsăud, Pucioasa, Fieni, Găeşti), those with tourist potential (Băile Herculane, Eforie, Băile Govora), and those with national importance as regards railway transport (Jibou, Făurei).

Degree of rurality has another calculating method, based on the rural population share in small towns (the share of population in the included localities), as well as population occupied in agriculture (essential for establishing the agricultural profile of small towns). The values are standardized and then the weighted average is calculated with the following formula:

$$
\mathrm{RP}_{\mathrm{I}}=(2 \text { pop. occ. in agric. }+ \text { rural pop. share }) / 3
$$

The highest rural degree (excessive - over 0.4 ) is met in south and south-east, where there are many towns with agricultural function (Vânju Mare, Mihăileşti, Pogoanele, Însurăței, lanca) or with a great share of population in the included localities (Baia de Aramă). Also high rural levels (0.20-0.40) have the small towns situated in the Sub-Carpathian or mountainous areas, where the share of the "rural" population is considerable (Fig. 5). 
The majority of towns have an average rural character $(0.20-0.10)$; this category includes the towns with a smaller rural population or a (less) significant population share occupied in agriculture.

The smallest rural level is characteristic of those towns which either had a specific industrial development in the 1970s-1980s - Cavnic, Vlăhița, Bocşa, Copşa Mică, Victoria and so on) or of the resorts (the majority of the population being occupied with services) - Slănic-Moldova, Sinaia, Vatra Dornei, Borsec, Băile Tuşnad etc.

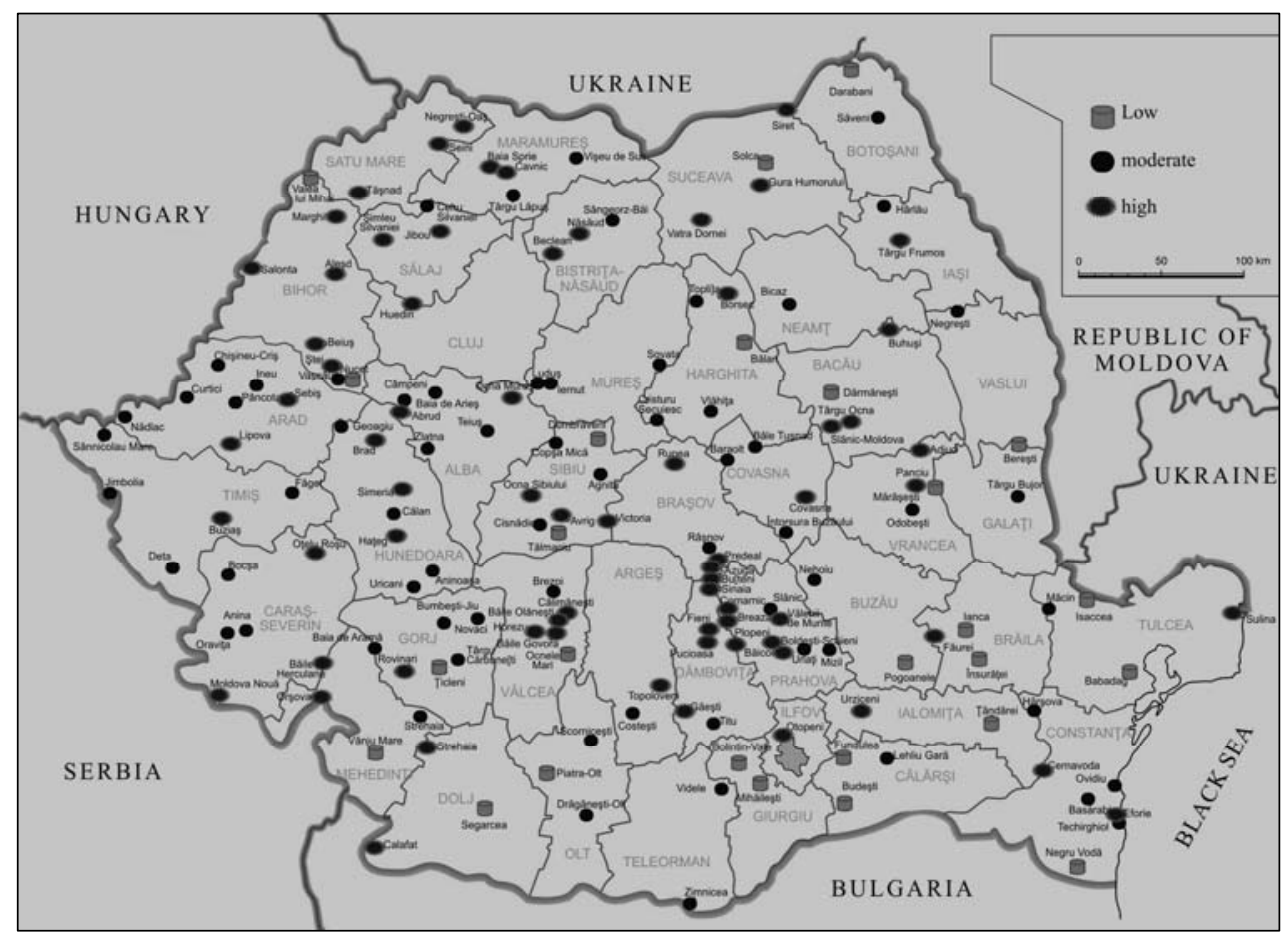

Fig. 4 - Territorial distribution of the development index by towns (2002)

There are other cases too, but the majority of these towns are characterized by specific rural aspects, thus having an ambiguous status.

\section{Functional Profile of Small Towns}

The economic changes in small towns, especially in 1975-1985, represented the main factor in their functional and demographic differentiation, the basic restructuring of their occupied population depending on the economic sectors.

The main functional types were established on the basis of the statistical records in the population censuses in 1966, 1992 and 2002, related to occupied population structure. In addition, there were some other adjustments to the economic profile of towns; thus 10 types were established. Statistical values were not absolute, but were used as a rough guide only, the correlation with the economic profile being facilitated by the existence of some similar 
approaches in the geographical literature. The main three functional types are the following: industrial, farming and services; they had, roughly, a share of $60 \%$ of the total occupied population in one of the three fields.

The complex type is characteristic of towns with a share of about $30 \%$ occupied population in the three sectors (primary, secondary, tertiary). The following functional types are derived from the above-mentioned ones: industrial and services, services and industrial for the small towns with a share of $40-60 \%$ occupied population for the first domain and $40 \%$ for the second one, respectively. A specific study was made on the change of the analyzed functional type, underlying the factors with a very important function in the configuration and dynamics of the present structures.

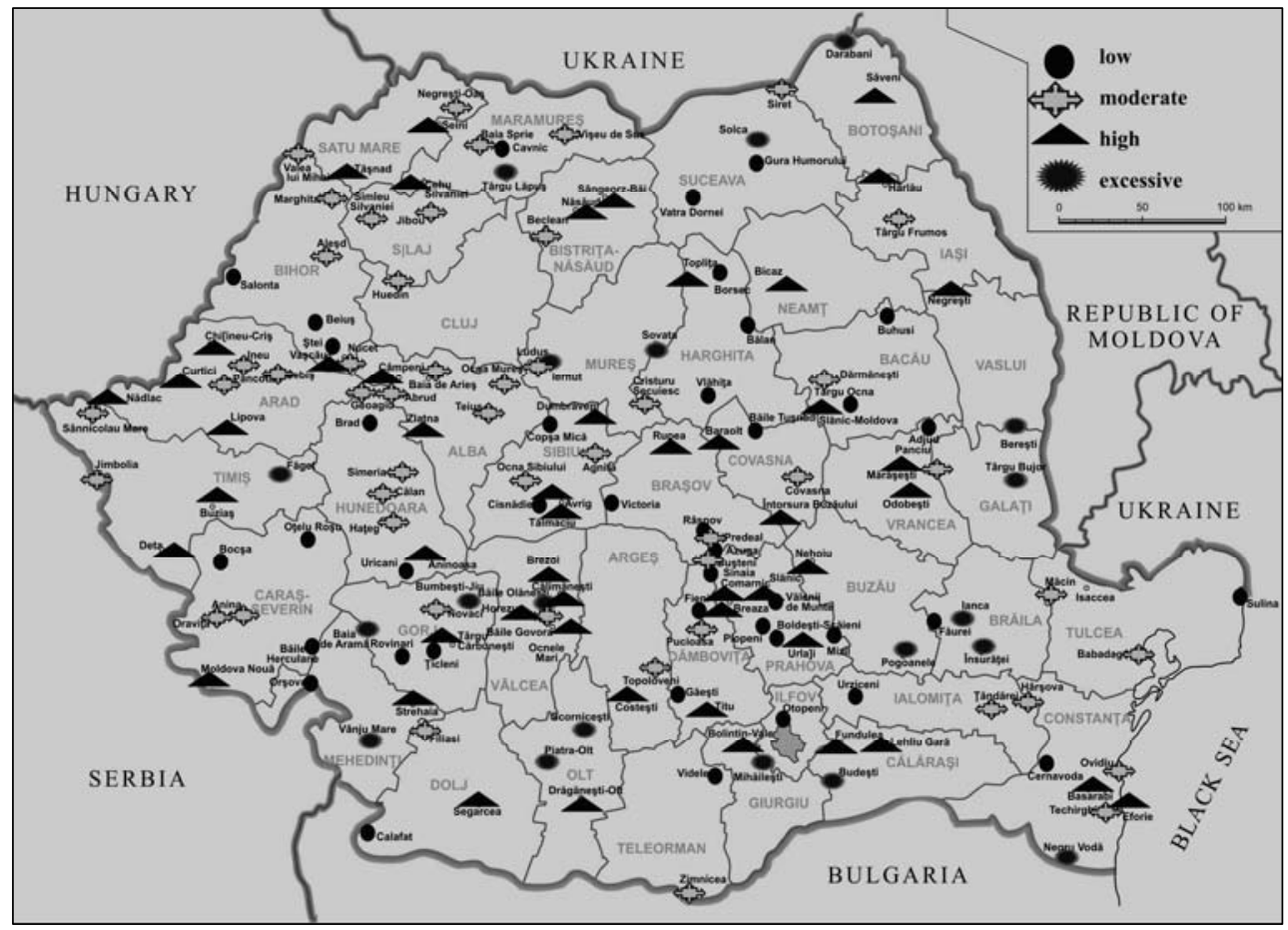

Fig. 5 - Rurality degree of small towns in Romania

Before initiating a regional analysis on the functional types of the towns, the small towns should be presented in the two census years, namely 1992 and 2002. The comparative study reveals the significant changes with a great economic impact on the small towns, the most important one being a decrease in the number of towns with industrial profile and an increase in the number of the service-oriented ones (even if in the majority of cases it is trade and not other tertiary activities). It can be noticed an increasing number of small towns with primary activities, but also a simultaneous decrease of the industrial sector share in the activities of these towns (Fig. 6). 


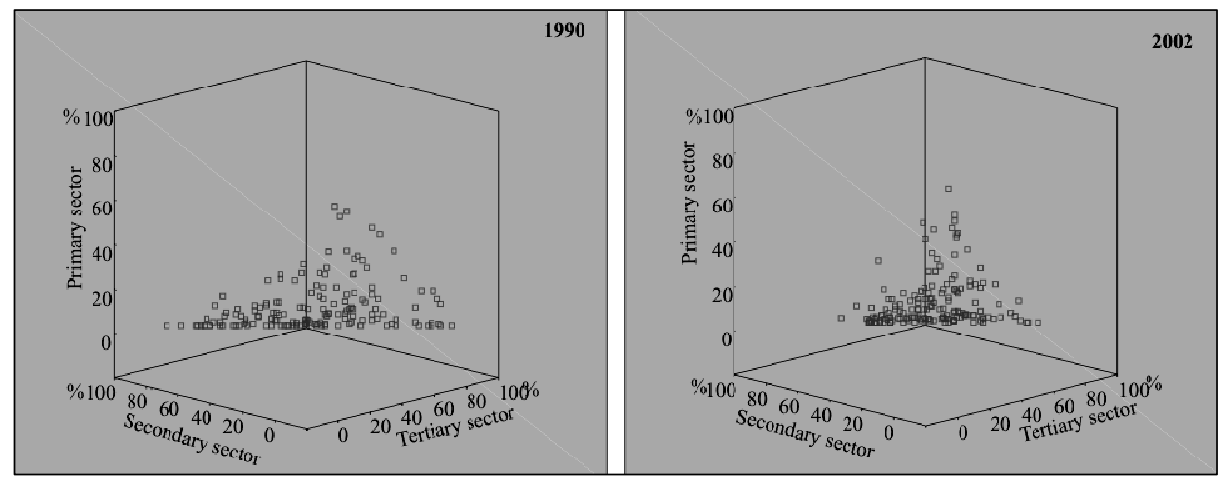

Fig. 6 - Functional profile of small towns

The real phenomenon is, actually, the economic diversification within towns which, before 1990, were super-specialized (industrial mono-functional), by a significant emergence of the tertiary sector (a very normal and predictable phenomenon).

With respect to the functional structure, the most numerous towns have industrial and service functions (23) and service and industrial ones (22), representing $28 \%$ of the total number of small towns. They are followed by towns with industrial function (42), which represent $26.01 \%$ of the total number of small towns. These types are related, especially, to the forced industrialization policy and exploitation of natural resources, characteristic of the former political regime. The services were expanded after 1990, not due to their extraordinary development, but to the decline of industrial activity, the result being that their statistical share increased considerably; it was rather a "natural" gradual normalization, since the tertiary process represents the main characteristic of towns in the developed countries.

The towns with industrial and service functions represent $14.4 \%$ (23) of the total number of 161. They are concentrated in the south and north-west of the country, in rural areas, and have a significant local polarization function, a result of their important demographic growths in 19661992: between $20 \%$ and 100 . The industrial function is given by the existence of some industrial units, usually small, and the service one by the traditional commercial or transport or tourist and spa (Slănic Moldova) functions of some of them. The industrial units exploit, usually, some local agricultural, forest or non-metallic resources (Mizil, Moldova Nouă).

There are 22 towns with service and industrial functions, i.e. $13.6 \%$ of the total. This category includes many towns which combine tourist and industrial functions. Additionally, there are those which have transport and industrial activity functions, related to the main function, and another category represented by the towns with commercial and industrial functions (Tg. Frumos). This category also includes industrially developed towns in the socialist period, but which lost ground after 1990, because of the economic restructuring. In exchange, service function improved, both for their population and for the nearby area ((Filiaşi, Negreşti Oaş, Buhuşi).

The industrial towns, 42 in all, have a $26.01 \%$ share, being situated in deeply industrialized areas and having mining functions (Aninoasa, Rovinari, Baia Sprie, Cavnic); some other industrial towns are in Prahova and Sibiu counties. Depending on the viability of industrial units, 
as well as on the environment quality, some of them registered population growth (Baia Sprie, Bocşa, Bicaz, Râşnov s.o.), whereas others, a decrease in population (Anina). In the latter case, we should mention the significant influence of mass migration of the German population after 1990. The spatial distribution of the industrial towns reveals the areas with an exacerbated industrial development (Hunedoara-Gorj group, Harghita group, Sibiu and Prahova group). In comparison with 1992, the number of towns with industrial profile has decreased significantly, with more than $10 \%$, many of them changing their profile into a service or complex one, especially those with artificially developed industry (Scorniceşti, Jimbolia, Siret, Beclean, Năsăud) or those which have turned to their tradional service functions (Sinaia, Buşteni, Azuga).

The service-function towns (Băile Herculane, Băile Govora, Călimaneşti, Predeal, Băile Tuşnad, Techirghiol, Eforie, Făurei) have a spa or resort function (except for Făurei which is a very important national railway junction); their influence on the nearest rural area is small. They increased in 1992-2002 and are 26 at present, meaning $16.14 \%$ of the total of small towns. There are also service-function towns having polarization role (Ineu, Sebiş, Oravița, Rupea, Şimleul Silvaniei, Huedin); their industrial function has considerably decreased lately.

The towns with mixed functions (Odobeşti, Mărăşeşti, Segarcea, Videle) are either former rural settlements with agricultural function which benefitted from many industrial units with a capitalization role of local resources (Segarcea), or former industrial towns (lernut, Baraolt). Some of them are situated in deeply rural areas, being important attraction poles (Târgu Lăpuş, Săveni). The three main sectors have relatively equal shares in the structure of the occupied population.

The towns with agricultural functions are 17 in all $(10.5 \%$ of the total of small towns), represented by localities situated in agricultural areas (Fundulea, Budeşti, Drăgăneşti Olt, Pogoanele, Mihăileşti). Their characteristic is the localization in agricultural areas, even if Mihăileşti is in the influence area of the Capital. All these towns are located at inferior levels of the urban hierarchy, both at national and county level. Their demographic dynamics is a regressive one, overlapping the preservation of the initial functional structure. Many of them have an agricultural profile, also due to the great number of constitutive localities in which the population is occupied especially with agriculture (Vânju Mare, lanca, Târgu Bujor).

\section{Evolution of the Small Town Identity - Past, Present and Future}

In the previous century, the identity of the Romanian small towns underwent significant changes. There was a rather "closed system" with massive inputs (represented by an increase in both the number of towns and in their population) that, under the influence of political and economic changes, generated quantitative and qualitative modifications in their structure. After the 1989 Revolution, some of them regained part of their initial identity (that before 1950) or reached a higher level.

Thus, three periods of time could be detected:

- Before 1950, the towns were deeply rural, having similar activities to those of rural communities;

- 1950-1989, when their identity was completely changed, because of the communist regime; this was the main reason for all the negative changes. Therefore, some distortions appeared both in the national and regional urban systems, mainly because of the state brutal interference in their physical and functional configuration (lanoş, 1997). 


\begin{abstract}
Among the most important reasons generating indirect distortions were the socialist industrialization and "cooperativization" of agriculture; the direct ones were related to the manner in which the administrative status of "towns" was decreed; assignment of new urban functions; and territorial and urban systematization policy. Preponderant urban industrialization determined an increased attractiveness for the rural population and a boom of small and medium-sized towns.
\end{abstract}

Cooperativization of agriculture favored the depopulation of villages by labor force migration to the new working places in towns which could not meet the requirements of the new economic changes imposed by a super-centralized regime.

The emergence of new towns had a direct impact on the urban system. If, before 1966, the new towns were decreed in a rather isolated manner, especially for some national industrial activities, after that they were decreed at the same time, in groups (for example, 51 in 1968 and 23 in 1989); other criteria were also taken into account, some rather subjective (for example the communes in which some great personalities of the regime were born).

The greatest changes were determined by the synergic action of the new municipalities, which gained this function after political and administrative restructuring in 1968. Their geographical distribution and the huge funds changed them into "genuine aspirators" of labour and material resources. Their excessive development comparative to other towns generated new distortions in the urban system, both hierarchical and territorial, with negative impact mainly on small towns and rural settlements, which suffered a significant depopulation.

The territorial and urban systematization policy was another direct reason for increasing the distortions in the Romanian urban system. Territorial development programmes, with the county as basic administrative unit, had in view the municipality, especially in the smallest ones:

After 1989, in a democratic political regime, several towns tried to regain their former identities "stolen" by the communist regime. Following economic restructuring, numerous industrial units closed down and economy reoriented. Therefore some inhabitants chose to take back their former agricultural activity and others to work in industrial units and part time in agriculture. These towns had an economic direction to services.

The obvious difference from the former stage is that, if before 1989, the identity was conventional and constrained, nowadays it is about to be achieved in a natural process conditioned only by the town and its inhabitants. Also, if in the past the majority of ideas determining a specific direction came from outside, nowadays local and personal decisions can be chosen and implemented, not necessarily with a national executive supervision.

The future of a town is very difficult to predict on a medium or long term. However, research on size and activity changes within a town reveal some interactions leading to a conclusion on their evolution. Thus, the position of a town comparative to the others, together with which it makes up a system, is an important factor in analyzing the evolution of that town. From geographical point of view, relative size and specialization, a conclusion can be drawn as regards dependency on historical background, its former adaptation, and its evolutional direction; also the effect entailed by the competition with other towns.

The identity of small towns, defined on the basis of their position in the national hierarchy of settlements, does not exclude spatial diversity, which is both the result of the geographic 
environment and of the former policy. Small towns have been identified separately in units in rural areas, industrial ones, and those situated close to a city or a big town. A similar size corresponds to different geographical positions. Besides their spatial distribution, the varied characteristics of the small towns and the changes which influenced them in time are even more important.

\section{Conclusions}

During their evolution, some small towns extended and changed their administrative status: they became medium-sized towns. Likewise, they might have known a significant population growth, but still remained small towns. They could change because the environment got deeply urban or industrialized. In all cases, small towns are not a static category in time; on the contrary, they can be considered as unstable and fugitive, with varied "inputs and outputs" as a whole.

Between diffusion and polarization, small towns represent a frail territorial aspect, remaining always structural, but with powerful changes in its structure, in the activity elements, in its permanent progressive direction.

This hypothesis can be verified and analyzed by the way in which small towns changed from the functional point of view during the 20th century; also how this urban hierarchy level is integrated within the Romanian territory.

\section{Bibliography}

BRUYELLE P. (1972), Le role des petites villes en milieu urbaine: l'exemple de la region du Nord, Bulletin de l'Association des Geographes Francaises, no 400-401.

CATTAN Nadine, PUMAIN Denise, ROZENBLAT C., SAINT-JULIEN Therese (1994), Le systeme des villes europeennes, Coll. Villes, Economica, Paris.

CATTAN Nadine, SAINT-JULIEN, Therese (1999), Devenir urbains: les villes petites et moyennes, L'information Geographique.

CHAMPION A. G. (1998), Population trends of small and medium-sized towns in non-metro regions, Revue de Geographie de Lyon, Volume 73, no 1.

DE MAXIMY R. (1987), Un developpement fonde sur les petites villes?, Annales de Geographique, no 535.

DEICĂ P., ERDELI G. (1994), Les petites villes de Roumanie, Institutul de Geografie al Academiei Române, Bucureşti.

DI MEO G. (1997), Bourg et petites villes, nouvelles actives, nouvelles fonctions, in Bourgs et petites villes, Acte du Colloque de Nantes du 23-25 mars 1995, Presses Universitaire du Mirail, Coll. Villes et Territoires, Tolouse.

EMSELLEM Karine (1999), Les petites villes roumaine, Paris I-Sorbonne, doctorale dissertation.

GIRAULT F.(1997), Les petites villes frncaises, entre metropolisation et France profonde, în Bourgs et Petites villes, Acte du Colloque de nantes du 23-25 mars 1995, Presses Universitaire du Mirail, Coll. Villes et Territoires, Tolouse.

IANOŞ I. (1982), The place and function of small towns, Terra no. 3.

IANOŞ I. (1987), The Town and Structure of the Geographical Space. Economic Geographic Study on the Romanian Territory, Editura Acdemiei, Bucureşti.

IANOŞ I, TĂLÂNGĂ C. (1994), The Town and Romanian Urban System on the Present Economic Background, Institute of Geography, Bucureşti.

IANOŞ I. (1994) On the central place functions of the rural settlements in Romania, 
Revue Roumaine de Géographie, 38.

IANOŞ I., TĂLÂNGĂ C. (1996), The Structure and Dynamics of Small Towns in Romania, Geographical Regional Conference, vol. II, Timişoara. Bucureşti. IANOŞ I., HUMEAU J.P. (2001), Teoria sistemelor de aşezări umane, Editura Tehnică, IANOŞ I. (2004), Dinamica urbană, Editura Tehnică, Bucureşti. no 2.

KAYSER B. (1972), Les petites villes francaises, Revue de Geographie Alpine, vol 60,

LABORIE J.P. (1979), Les petites villes, Edition CNRS, Paris.

LABORIE J. P. (1997), Les petites ville et la metropolisation, in Bourgs et petites villes, Acte du Colloque de Nantes du 23-25 mars 1995, Presses Universitaire du Mirail, Coll. Villes et Territoires, Tolouse.

LUGANE J.C. (1994), Les petites villes face a la metropolisation, Espace et Societe , no 73.

MATHIAN H., PUMAIN Denise, SANDERS Lena (1998), La transition urbaine: du preau post-industriel, în Des oppida aux metropoles, Archaeomedes, Coll. Villes, Anthropos, Paris. PUMAIN Denise (1999), Quel role pour les villes petites et mozennes de regions peripherique?, Revue de Geographie Alpine, no 2, tom 87, Berna.

RENARD J. (1997), Les bourgs ruraux, in Bourgs et Petites villes, Acte du Colloque de Nantes, Presses Universitaires du Mirail, Coll Villes et Territoires, Tolouse.

SANDERS Lena, MATHIAN H. (1998), Attraction urbaine et contexte d'urbanisation, in Donnees urbaines, Anthropos, Paris.

TĂLÂNGĂ C. (1994), The Way and Size of the Industry Restructuring Process within Romanian Villages, An. Univ. Bucharest, XLIII.

VEYRET-VERNER Germaine (1970), Essai de definition et de clasification des petites villes: leur insertion dans un reseau urbain, Revue de geographie alpine, LVII, no. 1.

ZAMFIR Daniela, BRAGHINĂ C. (2001) Geographical Considerations on the Small Towns' Hierarchy, Geographical Conferrences, „University” Publishing House, Bucharest.

*** (1938-1941), General Romanian Population and Settlements Census on December the 29th 1930, I-X, ICS, Bucharest.

*** (1970), General Romanian Population and Settlements Census on March the $15^{\text {th }}$ 1966, I-II, DCS, Bucharest.

*** (1980), General Romanian Population and Settlements Census on January the $7^{\text {th }}$ 1977, I-II, DCS, Bucharest.

${ }_{* * *}(1980)$, General Romanian Population and Settlements Census on January the $5^{\text {th }}$ 1977, I-II, DCS, Bucharest.

*** (1994), General Romanian Population and Settlements Census on January the $7^{\text {th }}$ 1992, I-III, CNS, Bucharest.

*** (2004), General Romanian Population and Settlements Census on March the $18^{\text {th }}$ 2002, I-IV, INS, Bucharest. 